\title{
Epiphytic Bacteria and Yeasts on Apple Blossoms and Their Potential as Antagonists of Erwinia amylovora
}

\author{
P. Lawrence Pusey, Virginia O. Stockwell, and Mark Mazzola
}

First and third author: U.S. Department of Agriculture, Agricultural Research Service, Tree Fruit Research Laboratory, Wenatchee, WA 98801; and second author: Department of Botany and Plant Pathology, Oregon State University, Corvallis 97330. Accepted for publication 7 February 2009.

\section{ABSTRACT}

Pusey, P. L., Stockwell, V. O., and Mazzola, M. 2009. Epiphytic bacteria and yeasts on apple blossoms and their potential as antagonists of Erwinia amylovora. Phytopathology 99:571-581.

Apple blossoms were sampled for indigenous epiphytic populations of culturable microorganisms during different stages of bloom at two locations in central Washington State and one site in Corvallis, OR. Frequencies and population sizes of bacteria on stigmas of apple were lower in Washington than at Corvallis, where average relative humidity was higher and possibly favored greater colonization; however, bacteria at Corvallis were mainly pseudomonads, whereas those in Washington were diverse, composed of several genera. In Washington, yeast as well as bacteria were isolated from both stigmatic and hypanthial surfaces.
Sampled blossoms were processed immediately to assess microbial populations, or after a $24-\mathrm{h}$ incubation at $28^{\circ} \mathrm{C}$ and high relative humidity, which broadened the range of detectable taxa evaluated as potential antagonists. Identifications were based on fatty acid methyl ester profiles and rDNA sequence analyses. Yeasts or yeastlike organisms were detected at frequencies similar to or greater than bacteria, particularly in hypanthia. When microbial isolates were tested for their capacity to suppress Erwinia amylovora on stigmas of detached crab apple flowers, many were ineffective. The best antagonists were the bacteria Pantoea agglomerans and Pseudomonas spp. and a few yeasts identified as Cryptococcus spp. Further evaluation of these taxa on flowers could lead to the discovery of additional biocontrol agents for fire blight.
Microbial communities on aerial plant surfaces are diverse and include many different genera of bacteria, yeasts, and filamentous fungi that affect plant health as pathogens, symbionts, and antagonists of disease organisms $(28,29)$. On leaf surfaces, bacteria are most abundant, followed by yeasts; filamentous fungi are considered transient inhabitants present mainly as dormant spores (3). For diseases caused by pathogens with an epiphytic stage in their life cycle, such as many bacterial diseases, indigenous microbial populations can affect the outcome of plant-pathogen interactions prior to infection $(6,29)$. Thus, many research programs are directed toward characterization of microorganisms that live epiphytically on plants, where they individually or jointly reduce plant disease. Such investigations can lead to an understanding of interactions affecting disease development. Although the microbial ecology of foliar surfaces has been studied extensively in relation to disease development (29), less is known about microbial communities on floral surfaces, which also serve as infection courts for many plant pathogens.

Blossoms of apple and pear are the primary sites where Erwinia amylovora, the causal agent of fire blight, becomes established epiphytically and initiates infection (58). The pathogen grows mainly on stigmas, which have a moist and nutrientrich surface (46), and subsequent rain or heavy dew facilitates its movement to the cup-shaped hypanthium where infection occurs through nectarthodes (55). Dilution of nectar in the hypanthium by water is also thought to decrease osmotic pressure and increase the suitability of this environment for bacterial colonization $(20,41,55)$. Management programs for fire blight have empha-

Corresponding author: P. L. Pusey; E-mail address: larry.pusey@ars.usda.gov

doi:10.1094/PHYTO-99-5-0571

This article is in the public domain and not copyrightable. It may be freely reprinted with customary crediting of the source. The American Phytopathological Society, 2009. sized risk assessment (7) and suppression of E. amylovora on floral parts with antibiotics $(39,58)$. Reliance on streptomycin, in particular, led to pathogen resistance in many production areas $(34,39)$.

Microbial suppression of E. amylovora on floral surfaces, particularly the stigmas (22), is a viable alternative or complementary measure to antibiotics (30,51). In 1996, Pseudomonas fluorescens strain A506, initially selected based on its inhibition of an ice-nucleating strain of Pseudomonas syringae on corn leaves (27), became the first commercially available antagonist for fire blight management (BlightBan A506; Nufarm Americas Inc., Burr Ridge, IL) (22). Bacteria present in other products now available or under development for this disease include strains of Pantoea agglomerans $(15,16,59)$ and Bacillus subtilis (9). Yeasts or yeastlike species being evaluated in commercial preparations include Aureobasidium pullulans, Candida sake, and Metschnikowia pulcherrima $(13,21)$.

Until bacterial populations on pear blossoms in the northwestern United States were studied by Stockwell et al. (52), little was known about the population sizes, distributions, or diversities of indigenous bacteria on these floral tissues. Likewise, there has been a lack of detailed information in the literature regarding epiphytic microorganisms on apple blossoms, even though many epiphytic organisms have been obtained from aerial surfaces of apple and evaluated as antagonists of E. amylovora (22). Methods used for screening and selection of microbial antagonists of $E$. amylovora have evolved from the use of artificial media $(5,19)$ to laboratory procedures with immature pear fruit $(60,65)$ and later to bioassays involving detached flowers or detached flower-bearing branches $(35,36,40)$. Media- and fruit-based assays have been useful for identifying and studying antagonistic strains that produce antibiotics inhibitory to E. amylovora, but results often do not correlate with suppression of the pathogen on blossoms $(14,62,63)$. Evaluation of microbial strains directly on flowers is more likely to identify antagonists effective on floral surfaces 
$(2,22)$, as supported by investigations of this approach $(36,40)$. A model system developed at Wenatchee, WA, involves crab apple, which can easily be manipulated to produce blossoms year round (40).

The first objective of our study was to characterize epiphytic populations of bacteria and yeasts on apple stigmas and hypanthia during primary bloom. The second objective was to evaluate the potential of major microbial taxa associated with apple blossoms as antagonists of E. amylovora by testing their capacity to suppress pathogen populations on stigmas of detached crab apple flowers.

\section{MATERIALS AND METHODS}

Orchard sites. Field sampling was performed at two locations in central Washington State and one orchard in Corvallis, OR. The sites in Washington were Washington State University (WSU) Tree Fruit Research and Extension Center (TFREC) in Wenatchee, WA, and WSU-U.S. Department of Agriculture (USDA) Columbia View experimental orchards located north of Wenatchee, 17 miles from TFREC. The sampling orchard in Corvallis was Brooklane Specialty Apples.

At each site in Washington, 20 trees of each apple cultivar, Gala and Red Delicious (Malus pumila), planted in 1990 or 1991 (4 or 5 years prior to the study), were selected. The cultivars were chosen because they represent common commercial cultivars considered as "most" and "least" resistant to fire blight, respectively, according to van der Zwet and Beer (57). Trees were located in different randomized complete blocks within WSU cultivar training-system trials; as an exception, Red Delicious trees at Columbia View were selected randomly within a mixed-cultivar block that was part of the USDA virology program. Twenty trees were used per cultivar and location; however, because Gala trees at Columbia View were small, 20 pairs of adjacent trees were used. Weather was monitored at each site in Washington with the EasyLogger 900 Recording System (Omnidata International, Inc., Logan, UT), and data collected included mean hourly temperature, relative humidity, and precipitation.

In the orchard at Corvallis, where rows of Gala were interplanted in 1987 ( 7 years prior to the study) with rows of $\mathrm{cv}$. Jonagold apple, 10 Gala trees scattered in the orchard were selected for sampling. Daily weather data were obtained from the AgriMet system (Northwest Cooperative Agricultural Weather Network, U.S. Bureau of Reclamation, Boise, ID).

Blossom sampling for microbial colonization. Blossoms were selected on the periphery of trees, $\approx 1$ to $2 \mathrm{~m}$ above the orchard floor. All blossoms were marked at the initial sampling date (10 to $80 \%$ bloom) with plastic-coated colored wire or colored yarn tied around the pedicle. Petals on each marked blossom were partially expanded but covered the anthers and stigmas.

At least 10 and 20 blooms were marked per Red Delicious and Gala tree (or tree pair), respectively, at each site in Washington, and at least 24 blooms were marked per Gala tree in Corvallis. Blossoms were fully open within $24 \mathrm{~h}$ after marking.

Initial sampling dates were 15 April 1994 and 26 April 1995 at Columbia View, 13 April 1994 and 25 April 1995 at Wenatchee, and 21 April 1994 and 6 April 1995 at Corvallis. Blossoms were sampled every 2 or 3 days through petal fall. At each site in Washington, 80 blossoms were collected per date from Gala trees and 40 blossoms were collected from Red Delicious trees; in Corvallis, 40 blossoms were collected per date from Gala trees. In Washington, blossoms were removed using latex gloves and forceps, both of which were periodically rinsed in $95 \%$ ethanol, and placed in sterilized 24-well microtiter dishes or ice cube trays covered with aluminum foil; at Corvallis, blossoms were removed with flame-sterilized forceps and placed in sterilized 12-well microtiter dishes. After transporting blossoms to the laboratory, Red Delicious samples, half of the Gala samples from the
Washington sites, and all samples from the Corvallis site were dissected and processed for evaluating microbial colonization. To increase the number and range of detectable taxa on flowers to be evaluated later as potential antagonists, the other half of the Gala blossoms collected from the Washington sites were incubated for $24 \mathrm{~h}$ prior to processing. Each flower was held with cut pedicel in a 2-ml vial containing sterile water at $28^{\circ} \mathrm{C}$ (near-optimum temperature for growth of E. amylovora) and high relative humidity (90 to $95 \%$ ).

Stigmas of each flower from the Washington sites, along with portions of the supporting styles, were placed in a sterile microcentrifuge tube containing $1 \mathrm{ml}$ of sterile washing buffer $(10 \mathrm{mM}$ potassium phosphate, $\mathrm{pH}$ 7.0). After the corolla, calyx, and pedicle were removed, the remaining hypanthium was placed in a separate microcentrifuge tube with buffer. The tubes were vortexed briefly and placed in a sonication bath for $60 \mathrm{~s}$. Samples were again vortexed and serial dilutions spread on trypticase soy agar (TSA) (15 g of tryptone and $5 \mathrm{~g}$ of soytone [Difco Laboratories, Detroit] and $5 \mathrm{~g}$ of $\mathrm{NaCl}$ per liter of water). In 1994, samples were plated on TSA amended with cycloheximide $(50 \mu \mathrm{l} / \mathrm{ml})$ for detection of bacteria and on TSA amended with streptomycin $(50 \mu \mathrm{l} / \mathrm{ml})$ for detection of yeast and filamentous fungi. In 1995, the medium for bacteria detection was additionally amended with oxytetracycline $(50 \mu \mathrm{l} / \mathrm{ml})$, because resistance to streptomycin was indicated in some bacteria detected the previous year. Antibiotics were obtained from Sigma-Aldrich (St. Louis). Samples $(10 \mu \mathrm{l})$ in buffer containing tissue and two 100 -fold dilutions (made in washing buffer) were spread on a single plate.

The detection limit per flower for stigmas or hypanthium was $10^{2} \mathrm{CFU}$. Plates were incubated at $24^{\circ} \mathrm{C}$ for 3 days for total bacteria counts. A single, spatially isolated colony of each morphological type was randomly picked from each plate representing populations of $>10^{3}$ on flowers processed soon after collection and $>10^{6}$ on flowers incubated under high temperature and moisture conditions. The colonies were subcultured and preserved on silica gel at $20^{\circ} \mathrm{C}(26)$. Some common organisms with distinctive morphological characteristics, such as the yeastlike organism $A$. pullulans, were not isolated from every plate; however, colony counts and references to representative isolates were recorded.

At Corvallis, where the study was restricted to bacteria isolated from stigmas soon after transferring flowers to the laboratory, procedures were similar to those performed in Washington, except samples were plated on $20 \%$ preformulated TSA (Difco Laboratories) and subcultures were preserved in $15 \%$ glycerol in nutrient broth at $-80^{\circ} \mathrm{C}$.

Identification of microbial strains. Fatty acid methyl ester (FAME) analysis of whole-cell fatty acids was performed with isolates representing population levels of $\geq 10^{3} \mathrm{CFU}$ on floral tissues using standard procedures (37). Extractions from isolates were analyzed with gas chromatography (model 5890A; HewlettPackard Co., Avondale, PA) and Microbial Identification System (MIS) software (Microbial ID Inc., Newark, DE) using the aerobe method. MIS identifications were updated in 2008 with a 2002 library, the latest software modification available for existing equipment.

In 2008, representative isolates in each taxonomic group identified by FAME were also identified by rDNA sequence analyses. For bacteria, this involved $16 \mathrm{~S}$ rDNA (1) and, for yeasts, the internal transcribed spacer (ITS) region of rDNA (11). The rDNA sequence analyses were relied on more heavily when the average match to FAME profiles of known microbial strains was $<0.6$ similarity or when identifications by the two systems were different. Identifications of some groups were resolved by subjecting additional isolates to rDNA sequence analyses. The rDNA-based results, however, did not always allow us to distinguish species within the same genus (e.g., Pseudomonas); in these cases, specific identification was determined mainly by FAME analyses. Sequence data for 164 bacteria and 51 yeasts (or yeastlike 
organisms) were submitted to the National Center for Biotechnology Information using the BLASTN program to identify sequences possessing significant homology.

DNA was extracted from bacteria cultured on TSA essentially as described by Raaijmakers et al. (47). DNA (10 $\mathrm{ng} / \mu \mathrm{l})$ was amplified by polymerase chain reaction (PCR) using primers $8 \mathrm{f}$ and 1406R from conserved regions of the 16S rRNA gene (1). Reaction conditions were as previously reported (33). PCR product was purified using a Qiaquick purification kit (Qiagen, Valencia, CA) according to the manufacturer's instructions and sequenced using a Dye Terminator Cycle Sequencing Quick Start Kit and a CEQ 8000 Genetic Analysis System capillary-based DNA sequencer (Beckman Coulter, Fullerton, CA). Sequencing was conducted in one direction employing the primer $27 \mathrm{~F}(25)$.

Yeast DNA extractions were prepared using the UltraClean Microbial DNA Isolation Kit (Mo Bio Laboratories, Inc., Carlsbad, CA). DNA was amplified in reactions with the primers ITS4 and ITS5 (61) using conditions previously described (54). PCR products were treated using ExoSAP-IT (USB Corporation, Cleveland, $\mathrm{OH})$ and sequenced as described above in reactions with the primer ITS1 (61).

Evaluation of isolates as antagonists. Blossom assays were performed as described previously (40) with selected microorganisms from apple using flowers of 'Manchurian' (M. mandshurica) or 'Snowdrift' (Malus sp.) crab apple (Van Well Nursery, Wenatchee, WA). Tree bloom was induced in a greenhouse, and newly opened flowers were collected and each maintained with cut pedicle submerged in $10 \%$ sucrose in a $2-\mathrm{ml}$ vial. The vials were supported in plastic tube racks placed in a 4-liter plastic container.

Bacteria and yeasts were cultured on nutrient yeast dextrose agar ( $8 \mathrm{~g}$ of nutrient broth, $5 \mathrm{~g}$ of yeast extract, $5 \mathrm{~g}$ of dextrose, $15 \mathrm{~g}$ of agar, and 1 liter of deionized water) at $24^{\circ} \mathrm{C}$ for $24 \mathrm{~h}$. Inoculum suspensions were prepared in $10 \mathrm{mM}$ potassium phosphate buffer ( $\mathrm{pH}$ 7.0) and $0.03 \%$ Tween-20 and adjusted to 0.1 optical density at $600 \mathrm{~nm}$ using a spectrophotometer (Spectronic 20; Milton Roy Co., Rochester NY), resulting in bacteria at $\approx 10^{8} \mathrm{CFU} / \mathrm{ml}$ and yeast at $\approx 3 \times 10^{8} \mathrm{CFU} / \mathrm{ml}$. Then, $\approx 0.1$ to $0.2 \mu \mathrm{l}$ of suspension of each test organism was applied per flower by touching the aqueous meniscus extending from a micropipette tip to each stigma (five per flower) to form a thin film of moisture. Following incubation at $24^{\circ} \mathrm{C}$ and $90 \%$ relative humidity for $24 \mathrm{~h}$, E. amylovora was then applied using the same technique. Flowers were incubated at $24^{\circ} \mathrm{C}$ for another $24 \mathrm{~h}$. Size of the pathogen populations on stigmas was estimated as already described for blossom sampling, except the plating medium was CCT medium (defined by Ishimaru and Klos) (18) amended with nalidixic acid (100 $\mu \mathrm{g} / \mathrm{ml})$.

The pathogen used was a nalidixic acid-resistant derivative of E. amylovora strain Ea153, obtained from K. B. Johnson (Oregon State University) (23). A rifampicin-resistant derivative of Pantoea agglomerans strain C9-1 (19), also from Johnson (23), was used as a standard antagonist.

Assays were performed with bacteria and yeasts representing a number of taxonomic groups on multiple dates. Generally, five flowers were used per isolate and between 5 and 25 isolates were tested together per date and compared with control flowers inoculated with E. amylovora only. Some isolates were tested more than once.

Data analysis. Bacterial population size was determined separately for stigmatic and hypanthial tissues at each sampling date. Bacterial population size on individual blossoms was estimated directly from colony counts, and estimates were logarithmically transformed to base 10 prior to calculation of mean population size. In some treatments, the population size of culturable bacteria was commonly below the detection limit of $100 \mathrm{CFU} / \mathrm{sample}$. Therefore, as in a previous similar study with pear (52), population data were presented as two values: isolation incidence, defined as percentage of blossoms having population sizes of culturable bacteria exceeding the detection limit; and size of detectable populations, indicating the mean population size on those blossoms from which bacteria were detected. Together, the two values accurately represent the population data.

In each set of blossom assays performed on a single date, the potential of isolates as antagonists was expressed as mean population size of E. amylovora on flowers preinoculated with the test organism divided by the pathogen population size on control flowers inoculated with only E. amylovora. The antagonism index (AI) values were used to compare isolates tested on different dates and to summarize results of multiple assays with isolates representing diverse taxa. AI values for each taxon were averaged and standard errors calculated.

\section{RESULTS}

Weather conditions at sampling sites. Weather conditions at the Wenatchee and Columbia view locations in Washington State were similar in each year but contrasted with those at Corvallis, OR. Weather information is presented for one location in Washington (i.e., Wenatchee) and compared with weather data recorded at Corvallis (Fig. 1). The average temperature during the blossom sampling period in Wenatchee in 1994 was $14.9^{\circ} \mathrm{C}$, with a peak period at 4 and 5 days after petal expansion when the daily average was $>19^{\circ} \mathrm{C}$ and the daily maximum was $\approx 28^{\circ} \mathrm{C}$ (Fig. $1 \mathrm{~A}$ ); the overall temperature average in Wenatchee in 1995 was $11.9^{\circ} \mathrm{C}$ (Fig. 1E). By comparison, temperatures were lower at Corvallis, averaging 11.9 and $8.4^{\circ} \mathrm{C}$ for the sampling periods in 1994 and 1995, respectively (Fig. 1A and E). Relative humidity during the sampling period at Wenatchee fluctuated between daily minimum and maximum averages of 30.5 and $80.8 \%$ in 1994 and 28.3 and $87.8 \%$ in 1995 (Fig. 1B and F); overall average relative humidity in 1994 and 1995 in Wenatchee was 51.6 and 57.6\%, respectively. In contrast, average relative humidity during sampling at Corvallis in 1994 and 1995 was 82.9 and $84.7 \%$, respectively (Fig. 1B and F). Very little precipitation occurred in Wenatchee during the 2 years of the study, with just over $10 \mathrm{~mm}$ recorded on one day in 1995 (Fig. 1C and G). At Corvallis, trace amounts of precipitation occurred on several days in 1994 and exceeded $10 \mathrm{~mm}$ on 3 days in 1995 (Fig. 1D and H); total rainfall during sampling periods in 1994 and 1995 was 20.1 and $69.9 \mathrm{~mm}$, respectively.

Isolation of bacteria from apple blossoms in Oregon. Isolation incidence (i.e., percentage of blossoms that had detectable population sizes of culturable bacteria) increased in 1994 from

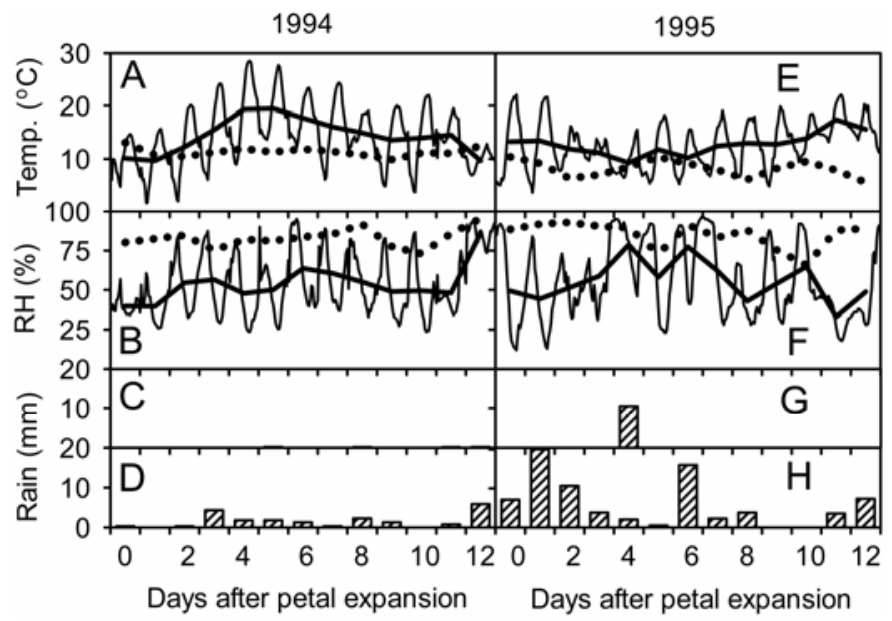

Fig. 1. Environmental conditions for apple orchards in A to D, 1994 and $\mathbf{E}$ to $\mathbf{H}, 1$ 1995. A and $\mathbf{E}$, Temperature and $\mathbf{B}$ and $\mathbf{F}$, relative humidity are presented as hourly data (thin line) at Wenatchee, WA, and as daily averages at Wenatchee (bold line) and Corvallis, OR (dotted line). Daily total rainfall is presented for $\mathbf{C}$ and $\mathbf{G}$, Wenatchee and $\mathbf{D}$ and $\mathbf{H}$, Corvallis. 
$3 \%$ on day 0 to $65 \%$ on day 4 , and reached $93 \%$ by day 12 (Fig. 2A); isolation incidence in 1995 increased from $8 \%$ on day 0 to $100 \%$ on day 8 (Fig. 2B). In both years, mean population size exceeded $10^{5} \mathrm{CFU}$ on the final sampling date (Fig. 2A and B). Predominant bacterial species detected on flower stigmas at levels of $\geq 10^{3} \mathrm{CFU}$ per flower were fluorescent pseudomonads, particularly Pseudomonas syringae and Pseudomonas fluorescens (Table 1). In 1994, Pseudomonas putida was frequent and Pseudomonas chlororaphis was also detected. Pantoea agglomerans was represented in both years on a few blossoms, and other bacteria identified as residents on single blossoms were Arthrobacter globiformis, E. amylovora, and B. cereus.

Isolation of bacteria and yeasts from apple blossoms in Washington. Due to relatively high daily temperatures and a high risk of fire blight in 1994, according to the Cougarblight riskassessment model (50), managers of WSU orchards applied oxytetracycline sprays (189 to 379 liters of $200 \mathrm{ppm}$ solution per acre) to apple trees at the Wenatchee site on 18, 19, and 21 April (sampling day 3, 4, and 6 after petal expansion) and to Gala trees at Columbia View on 19 and 21 April (sampling day 4 and 6). The antibiotic applications were undesired for the purposes of this study but outside our control. However, blossom sampling pre-

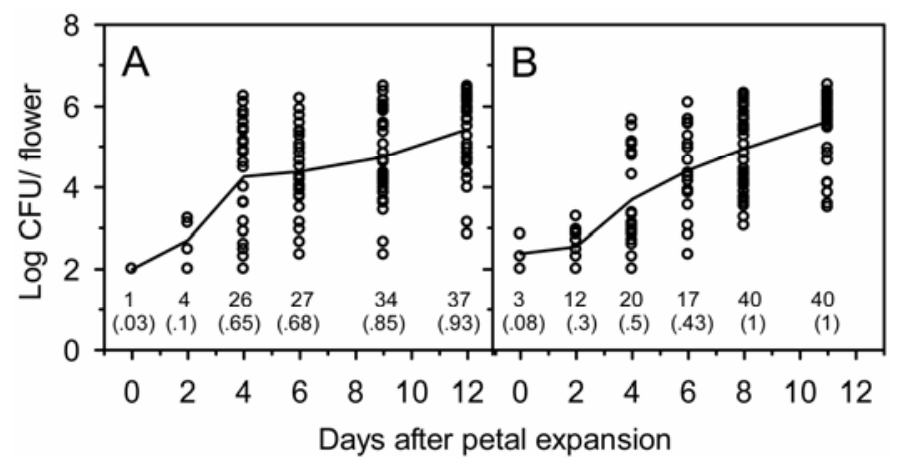

Fig. 2. Circles represent the population sizes of bacteria isolated on trypticase soy agar from stigmas of individual Gala apple blossoms sampled in Corvallis, OR, in A, 1994 and B, 1995. Forty blossoms were sampled on each date. Detection limit was $10^{2} \mathrm{CFU} /$ flower. Numbers above the $\mathrm{x}$-axis represent the number of samples with populations of bacteria; parenthetical numbers represent isolation incidence. Solid lines represent the mean population sizes of bacteria on each sampling date.

TABLE 1. Bacteria isolated from stigma surfaces of 'Gala' apple during primary bloom in Corvallis, OR

\begin{tabular}{lrc}
\hline Year, taxon & $\begin{array}{c}\text { Days after petal } \\
\text { expansion }\end{array}$ & $\begin{array}{c}\text { No. of } \\
\text { blossoms }\end{array}$ \\
\hline 1994 & & \\
Arthrobacter globiformis & 12 & 1 \\
Erwinia amylovora & 6 & 1 \\
Pantoea agglomerans & $2,6,12$ & $2-3$ \\
Pectobacterium carotovorum & 12 & 1 \\
Pseudomonas chlororaphis & $4,6,9$ & $1-2$ \\
Pseudomonas fluorescens & $2,4,6,9,12$ & $2-20$ \\
Pseudomonas putida & $2,4,9,12$ & $3-10$ \\
Pseudomonas syringae & $4,6,9,12$ & $7-18$ \\
1995 & & 1 \\
Bacillus cereus & 6,8 & 1 \\
Pantoea agglomerans & 4,8 & $1-8$ \\
Pseudomonas fluorescens & $2,4,6,8,11$ & 1 \\
Pseudomonas putida & 4,8 & $9-32$ \\
Pseudomonas syringae & $4,6,8,11$ & 1 \\
Pseudomonas sp. & 12 & 1 \\
Unidentified & 4,6 &
\end{tabular}

${ }^{a}$ Identifications were based on fatty acid methyl ester profiles and 16S rDNA analyses.

b Number of blossoms from which a strain was isolated on a given sampling date. Forty blossoms were sampled per date. ceded antibiotic sprays whenever the two activities occurred on the same day, and the Red Delicious block at Columbia View was left unsprayed.

When incidence and mean population sizes of bacteria on stigmas (as determined by processing flowers immediately after sampling) were compared among the apple blocks, oxytetracycline did not appear to greatly affect indigenous bacterial populations as expected. In all four apple blocks, incidence of bacteria on stigmas and hypanthia in 1994 increased from near $0 \%$ at the time of petal expansion, was highest at day 6 , and declined by day 9 . The frequencies of bacteria on stigmas of Red Delicious blossoms not treated with antibiotic were similar to those of apple cultivars at Wenatchee (Fig. 3A); frequencies for the three blocks on day 6 were 65 to $78 \%$. Incidences of bacteria on stigmas of Gala at Columbia View, however, appeared lower than those of the other blocks throughout the sampling period, even before oxytetracycline was applied ( $8 \%$ at day 3 compared with frequencies of 25 to $50 \%$ for the other orchard blocks). Mean population sizes of bacteria on stigmas generally peaked at day 6; on this sampling day, the apple block not treated with antibiotic showed a mean population size of log $2.8 \mathrm{CFU}$ per flower, and the average for the three antibiotic-treated blocks was $\log 2.4( \pm 0.07)$ CFU per flower. In 1995, when no antibiotics were applied during bloom, the frequencies of bacteria on stigmas in the four apple blocks increased from an average $\approx 20 \%$ on day 0 to a high occurring on day 7 or 9 of 60 to $93 \%$ (Fig. 3B). Mean population sizes of bacteria on apple stigmas increased to a maximum on day 7 or 9 ; in each block, mean values were always $\leq 10^{3} \mathrm{CFU}$ on day 0,2 , and 5 but sometimes between $10^{3}$ and $10^{4} \mathrm{CFU}$ on day 7 or 9 (means for individual blocks not shown).

Although Gala and Red Delicious were selected for study because they represent common commercially grown cultivars with different susceptibilities to fire blight, isolations of indigenous microorganisms from blossoms of these tree types at two locations were comparable. The complete data for Gala blossoms sampled from the Wenatchee site are presented (Figs. 4 and 5) as a representation of all apple blocks studied. In 1994, similar to results of bacteria on stigmas (Figs. 3 and 4A), the frequency of bacteria in hypanthia (Fig. 4B) and of yeasts on stigmas (Fig. 4E) and hypanthia (Fig. 4F) always increased to a maximum at day 6 . Mean population sizes of bacteria and yeasts on these tissues were generally highest on day 6; however, regardless of location or cultivar, the populations never exceeded log $2.8 \mathrm{CFU}$ per flower. In 1995, isolation incidence of bacteria and yeasts from blossom tissues was usually highest on day 7 or 9 (Fig. 5, top half). Mean population sizes of bacteria and yeasts on stigmas

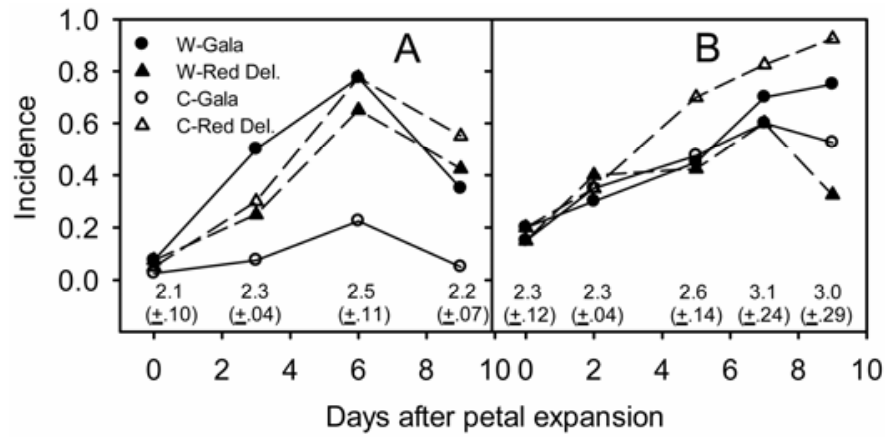

Fig. 3. Incidence of bacteria detected on stigmas sampled from four apple blocks in A, 1994 and B, 1995. Blocks consisted of cvs. Gala and Red Delicious at Wenatchee, WA (W-Gala and W-Red Del.) and the same cultivars at Columbia View (C-Gala and C-Red Del.), 17 miles north of the Wenatchee site. Solid and open symbols are used to distinguish locations; solid and dotted lines distinguish cultivars. Numbers above the $\mathrm{x}$-axis represent mean population size of bacteria ( $\log \mathrm{CFU} \pm$ standard error) when apple blocks are considered as replicates. Detection limit was $10^{2} \mathrm{CFU} /$ flower. 
(Fig. 5A and E) reached a maximum of between $10^{3}$ and $10^{4} \mathrm{CFU}$ on day 7 or 9 , and microbial population sizes on hypanthia (Fig. $4 \mathrm{~B}$ and $\mathrm{F}$ ) changed little, remaining at $<10^{3} \mathrm{CFU}$.

When Gala apple blossoms were incubated at $28^{\circ} \mathrm{C}$ and high relative humidity for $24 \mathrm{~h}$, the frequency and population sizes of bacteria and yeasts significantly increased as expected (Figs. 4 and 5, bottom half). In 1994, isolation incidence of bacteria from incubated blossoms from the two locations was highest for stigmas of flowers collected on day $3(\geq 98 \%$ ), declining to $\leq 48 \%$ for stigmas collected on day 9 (Fig. 4C); incidence of bacteria from hypanthia was high the first three sampling dates (93 to $100 \%$ ), with the exception of blossoms collected on day 6 from Columbia View (60\%), declining to $\leq 68 \%$ for blossoms on day 9 (Fig. 4D). By contrast, isolation incidence of yeasts from incubated blossoms was highest for samples collected on day 6 and 9: 73 to $100 \%$ for stigmas and 95 to $100 \%$ for hypanthia (Fig. 4G and $\mathrm{H}$ ). Mean population sizes of bacteria on stigmas and hypan-

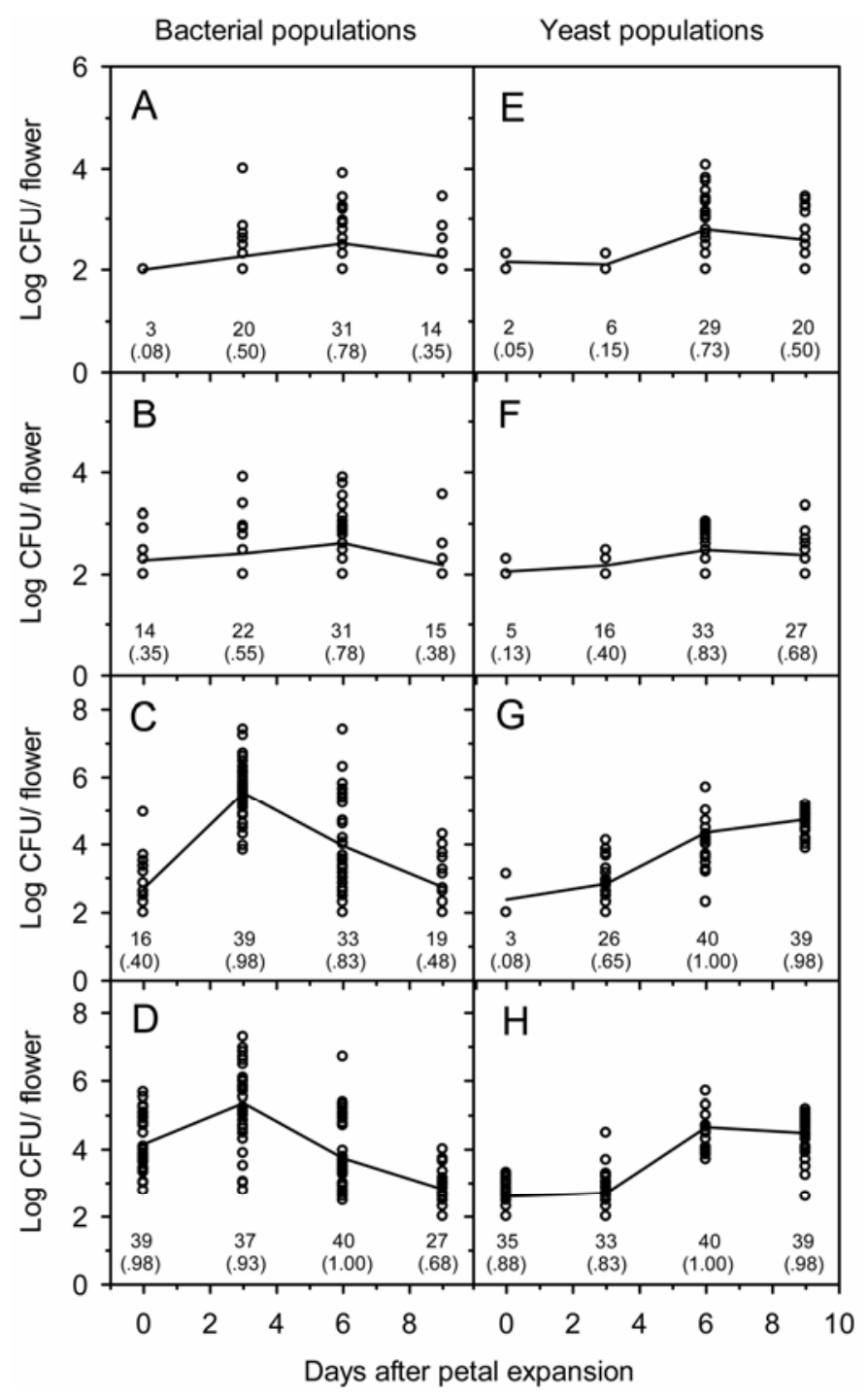

Fig. 4. Circles represent the population sizes of $\mathbf{A}$ to $\mathbf{D}$, bacteria or $\mathbf{E}$ to $\mathbf{H}$, yeasts isolated on trypticase soy agar from individual 'Gala' apple blossoms at Wenatchee, WA, in 1994. Microorganisms were isolated from the surfaces of $\mathbf{A}$ and $\mathbf{E}$, stigmas and $\mathbf{B}$ and $\mathbf{F}$, hypanthia immediately after sampling or from $\mathbf{C}$ and $\mathbf{G}$, stigmas and $\mathbf{D}$ and $\mathbf{H}$, hypanthia after blossom incubation at $28^{\circ} \mathrm{C}$ and high relative humidity for $24 \mathrm{~h}$. On each date, 80 blossoms were sampled; half were incubated and half were not incubated. Detection limit was $10^{2}$ CFU/flower (or flower part). Numbers above the $\mathrm{x}$-axis represent the number of samples with populations of bacteria; parenthetical numbers represent isolation incidence. Solid lines represent the mean population sizes of bacteria on each sampling date. thia of incubated blossoms peaked when samples were collected on day 3 (log CFU from 4.2 to 5.5 ), declining to $<10^{3} \mathrm{CFU}$ for blossoms collected on day 9 (Fig. 4C and D); mean population sizes of yeasts on tissues of incubated blossoms were at or near maximum levels for samples collected on day 9 (log CFU from 4.3 to 4.8 ) (Fig. $4 \mathrm{G}$ and $\mathrm{H}$ ). In 1995, all isolation incidences of bacteria from tissues of incubated blossoms were high, at 88 to $100 \%$ (Fig. 5C and D), with the exception of stigmas from Columbia View on day $0(60 \%)$. Incidences of yeasts from tissues of incubated blossoms sampled on day 0 and 2 were 10 to $75 \%$ but yeast frequencies for blossoms collected on day 5, 7, and 9 were 90 to $100 \%$ (Fig. $5 \mathrm{G}$ and $\mathrm{H}$ ). Mean population sizes of bacteria on incubated blossoms were always $>10^{5} \mathrm{CFU}$ on stigmas of blossoms collected after day 3 (Fig. 5C) and $>10^{5} \mathrm{CFU}$ on hypanthia of blossoms collected after day 0 (Fig. 5D). Mean population sizes of yeasts were always $>10^{4} \mathrm{CFU}$ on tissues of incubated blossoms collected after day 2 (Fig. $5 \mathrm{G}$ and $\mathrm{H}$ ).

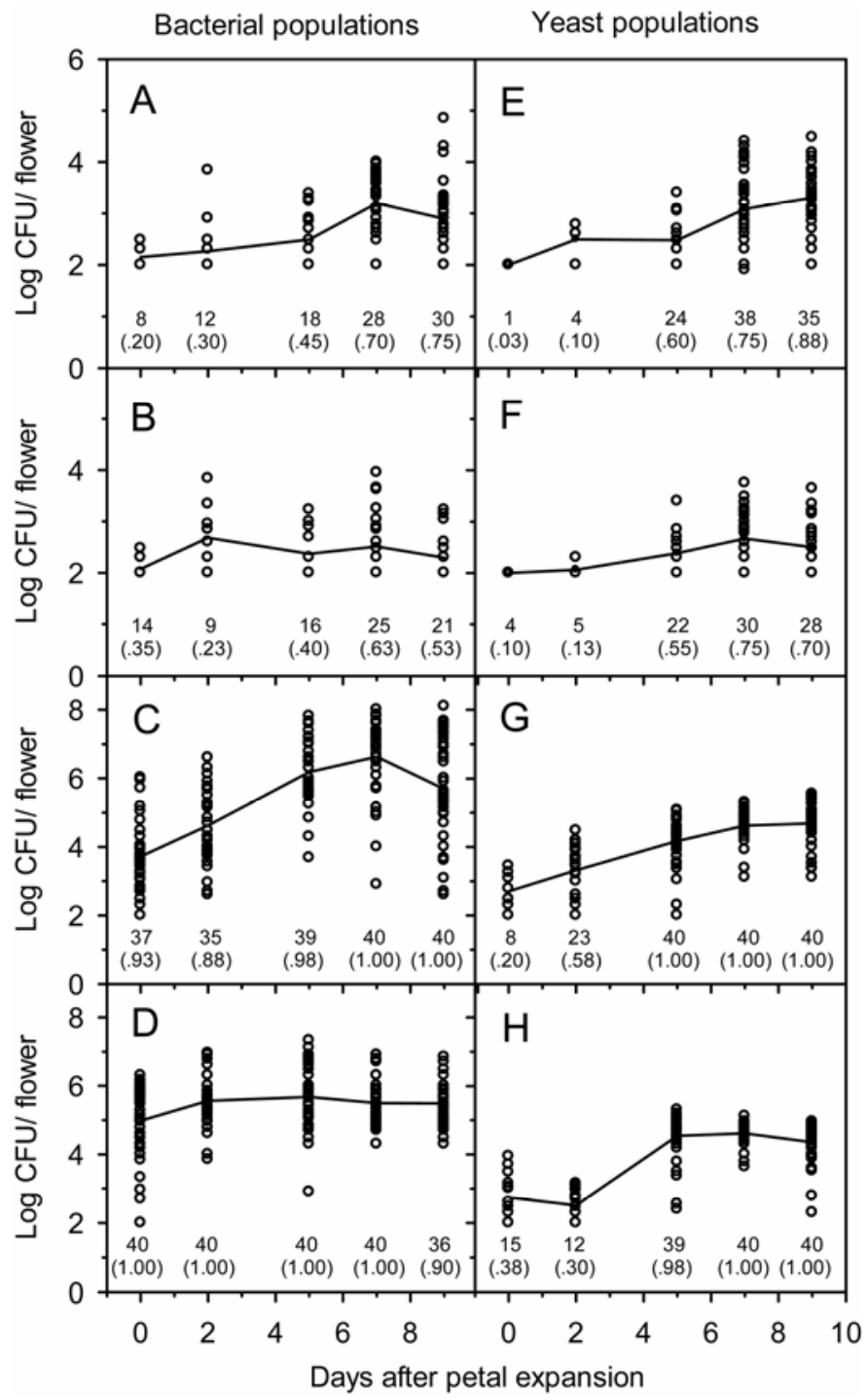

Fig. 5. Circles represent the population sizes of $\mathbf{A}$ to $\mathbf{D}$, bacteria or $\mathbf{E}$ to $\mathbf{H}$, yeasts isolated on trypticase soy agar from individual 'Gala' apple blossoms at Wenatchee, WA, in 1995. Microorganisms were isolated from the surfaces of $\mathbf{A}$ and $\mathbf{E}$, stigmas and $\mathbf{B}$ and $\mathbf{F}$, hypanthia immediately after sampling or from $\mathbf{C}$ and $\mathbf{G}$, stigmas and $\mathbf{D}$ and $\mathbf{H}$, hypanthia after blossom incubation at $28^{\circ} \mathrm{C}$ and high relative humidity for $24 \mathrm{~h}$. On each date, 80 blossoms were sampled; half were incubated and half were not incubated. Detection limit was $10^{2}$ CFU/flower (or flower part). Numbers above the $\mathrm{x}$-axis represent the number of samples with populations of bacteria; parenthetical numbers represent isolation incidence. Solid lines represent the mean population sizes of bacteria on each sampling date. 
In the four apple blocks studied in central Washington in 1994 and 1995, a diversity of bacteria were detected on blossoms. In 1994, genera represented at levels of $\geq 10^{3} \mathrm{CFU}$ on five or more blossoms were Actinobacterium, Curtobacterium, Microbacterium, and Pseudomonas (Table 2). When applying the same criteria in 1995, the genus Bacillus also stood out, along with those already listed (Table 3). These genera, with the exception of Bacillus, were isolated from both apple cultivars at both locations. Bacillus, specifically $B$. megaterium, was prevalent only at Columbia View on sampling day 7 and 9 in 1995. The most predominant genus in 1995 was Pseudomonas, particularly Pseudomonas putida (Table 3 ). Of total bacterial isolates identified in 1994 (Table 2), 16 were from stigmas and 11 from hypanthia, a stigma-to-hypanthium (S:H) ratio of 1.5 (Table 2); total identified isolates in 1995 (Table 3) from stigmas and hypanthia were 132 and 22 , respectively ( $\mathrm{S}: \mathrm{H}$ ratio of 6.0 ). For pseudomonads, the overall S:H ratio during the 2-year study was 8.0.

Yeast or yeastlike organisms detected on apple blossoms at $\geq 10^{3} \mathrm{CFU}$ were represented by four genera (Table 4 ). The yeast- like Aureobasidium pullulans and yeasts in the genus Cryptococcus were common on blossoms, particularly on late sampling dates. The two other yeast genera detected were Rhodotorula and Starmerella. Of the total yeast or yeastlike organisms identified in 1994, 30 were from stigmas and 15 from hypanthia ( $\mathrm{S}: \mathrm{H}$ ratio of 2.0); total identified isolates in 1995 from stigmas and hypanthia were 152 and 35, respectively (S:H ratio of 4.3). For A. pullulans, the $\mathrm{S}: \mathrm{H}$ ratio was 1.5 in 1994 and 3.7 in 1995 . For the genus Cryptococcus, the S:H ratio was 3.7 in 1994 and 6.8 in 1995.

Evaluation of epiphytic microorganisms as antagonists on blossoms. The large majority of microbial isolates tested on detached crab apple flowers as potential antagonists of $E$. amylovora (Table 5) were from flowers that had been sampled at locations in central Washington and incubated at $28^{\circ} \mathrm{C}$ for $24 \mathrm{~h}$; others were from nonincubated flowers sampled in Washington or at Corvallis. The incubation of blossoms increased the number and diversity of blossom-derived microorganisms that could be tested as antagonists. The same taxonomic groups represented on nonincubated blossoms generally increased on incubated blossoms,

TABLE 2. Bacteria isolated from stigmas (S) and hypanthia (H) of apple blossoms at two sites in central Washington State in 1994

\begin{tabular}{|c|c|c|c|c|c|c|}
\hline Taxon $^{b}$ & Days after petal expansion & Site & Cultivar & Tissue & $\mathrm{S}: \mathrm{H}$ ratio $^{\mathrm{c}}$ & No. of blossoms ${ }^{\mathrm{d}}$ \\
\hline Actinobacterium sp. & $0,3,6,9$ & $\mathrm{C}, \mathrm{W}$ & $\mathrm{G}, \mathrm{R}$ & $\mathrm{H}, \mathrm{S}$ & 2.0 & $1-3$ \\
\hline Aeromicrobium sp. & 3 & $\mathrm{~W}$ & $\mathrm{G}$ & $\mathrm{H}$ & $\ldots$ & 1 \\
\hline Arthrobacter globiformis & 9 & $\mathrm{C}$ & $\mathrm{R}$ & $\mathrm{S}$ & $\ldots$ & 1 \\
\hline Arthrobacter sp. & 6 & $\mathrm{~W}$ & G & $\mathrm{H}$ & $\ldots$ & 1 \\
\hline Bacillus cereus & 3 & $\mathrm{~W}$ & G & $\mathrm{H}$ & $\ldots$ & 1 \\
\hline Clavibacter michiganense & 3 & $\mathrm{~W}$ & $\mathrm{R}$ & S & $\ldots$ & 1 \\
\hline Curtobacterium flaccumfaciens & 0,6 & $\mathrm{C}$ & $\mathrm{R}$ & $\mathrm{H}, \mathrm{S}$ & 1.0 & 1 \\
\hline Erwinia amylovora & 3,6 & $\mathrm{C}, \mathrm{W}$ & $\mathrm{R}$ & $\mathrm{H}, \mathrm{S}$ & 0.5 & $1-2$ \\
\hline Microbacterium laevaniformans & 3 & $\mathrm{~W}$ & G & $\mathrm{H}$ & $\ldots$ & 1 \\
\hline Microbacterium spp. & 3,6 & $\mathrm{C}, \mathrm{W}$ & $\mathrm{G}, \mathrm{R}$ & $\mathrm{H}, \mathrm{S}$ & 1.0 & $1-3$ \\
\hline Pantoea agglomerans & 3 & $\mathrm{C}$ & $\mathrm{R}$ & $\mathrm{S}$ & $\ldots$ & 1 \\
\hline Pseudomonas florescens & 9 & $\mathrm{~W}$ & $\mathrm{R}$ & $S$ & $\ldots$ & 1 \\
\hline Pseudomonas syringae & 6 & $\mathrm{C}, \mathrm{W}$ & $\mathrm{G}, \mathrm{R}$ & $\mathrm{S}$ & $\ldots$ & 2 \\
\hline Pseudomonas spp. & 6 & $\mathrm{C}$ & $\mathrm{R}$ & $\mathrm{S}$ & $\ldots$ & 3 \\
\hline Rhizobium radiobacter & 0 & $\mathrm{~W}$ & G & $\mathrm{H}$ & $\ldots$ & 1 \\
\hline Unidentified & $3,6,9$ & $\mathrm{C}, \mathrm{W}$ & $\mathrm{G}, \mathrm{R}$ & $\mathrm{H}, \mathrm{S}$ & 0.3 & $1-5$ \\
\hline
\end{tabular}

a Blossoms were sampled from cvs. Gala $(\mathrm{G})$ and Red Delicious $(\mathrm{R})$ at research orchards at Wenatchee (W) and Columbia View (C).

${ }^{b}$ Identifications were based on fatty acid methyl ester profiles and $16 \mathrm{~S}$ rDNA sequence analyses.

c Ratio of the number of isolates from stigmas to the number from hypanthia.

${ }^{\mathrm{d}}$ Number of blossoms from which a strain was isolated on a given sampling date. Forty blossoms were collected per cultivar at each site.

TABLE 3. Bacteria isolated from stigmas (S) and hypanthia (H) of apple blossoms at two sites in central Washington State in $1995^{\text {a }}$

\begin{tabular}{|c|c|c|c|c|c|c|}
\hline Taxon $^{b}$ & Days after petal expansion & Site & Cultivar & Tissue & $\mathrm{S}: \mathrm{H}$ ratio $^{\mathrm{c}}$ & No. of blossoms ${ }^{\mathrm{d}}$ \\
\hline Acinetobacter sp. & 2 & $\mathrm{C}$ & $\mathrm{G}$ & $\mathrm{H}$ & $\ldots$ & 1 \\
\hline Actinobacterium spp. & $0,5,7,9$ & $\mathrm{C}, \mathrm{W}$ & $\mathrm{G}, \mathrm{R}$ & $\mathrm{H}, \mathrm{S}$ & 8.0 & $1-4$ \\
\hline Aeromicrobium $\mathrm{sp}$. & 7 & $\mathrm{~W}$ & $\mathrm{G}$ & $\mathrm{S}$ & $\ldots$ & 2 \\
\hline Arthrobacter aurescens & 9 & $\mathrm{C}$ & $\mathrm{R}$ & $\mathrm{S}$ & $\ldots$ & 3 \\
\hline Bacillus megaterium & 7,9 & $\mathrm{C}$ & $\mathrm{G}, \mathrm{R}$ & $\mathrm{H}, \mathrm{S}$ & 2.2 & $4-13$ \\
\hline Cellulomonas sp. & 7 & $\mathrm{C}$ & $\mathrm{R}$ & $\mathrm{H}$ & $\ldots$ & 1 \\
\hline Clavibacter michiganense & 7 & $\mathrm{C}, \mathrm{W}$ & $\mathrm{G}, \mathrm{R}$ & $\mathrm{H}, \mathrm{S}$ & 2.0 & 3 \\
\hline Curtobacterium flaccumfaciens & $5,7,9$ & $\mathrm{C}, \mathrm{W}$ & $\mathrm{G}, \mathrm{R}$ & $\mathrm{H}, \mathrm{S}$ & 5.1 & $1-4$ \\
\hline Erwinia sp. & 7 & $\mathrm{~W}$ & $\mathrm{R}$ & $\mathrm{S}$ & $\ldots$ & 1 \\
\hline Kocuria rosea & 5 & W & $\mathrm{R}$ & $\mathrm{S}$ & $\ldots$ & 1 \\
\hline Microbacterium spp. & 7,9 & $\mathrm{C}, \mathrm{W}$ & $\mathrm{G}, \mathrm{R}$ & $\mathrm{H}, \mathrm{S}$ & 7.0 & $2-4$ \\
\hline Micrococcus luteus & 7 & $\mathrm{~W}$ & $\mathrm{G}$ & $\mathrm{S}$ & $\ldots$ & 2 \\
\hline Micrococcus spp. & 9 & $\mathrm{C}$ & $\mathrm{G}$ & $\mathrm{H}, \mathrm{S}$ & 1.0 & 2 \\
\hline Paenibacillus sp. & 7 & $\mathrm{~W}$ & $\mathrm{R}$ & $\mathrm{S}$ & $\ldots$ & 7 \\
\hline Pseudomonas fluorescens & $5,7,9$ & $\mathrm{C}, \mathrm{W}$ & $\mathrm{G}, \mathrm{R}$ & $\mathrm{H}, \mathrm{S}$ & 9.1 & $3-4$ \\
\hline Pseudomonas putida & 7,9 & $\mathrm{C}, \mathrm{W}$ & $\mathrm{G}, \mathrm{R}$ & $\mathrm{H}, \mathrm{S}$ & 7.7 & $24-33$ \\
\hline Pseudomonas syringae & $2,5,7,9$ & $\mathrm{C}, \mathrm{W}$ & $\mathrm{G}, \mathrm{R}$ & $\mathrm{H}, \mathrm{S}$ & 8.0 & $1-8$ \\
\hline Ralstonia pickettii & 0 & $\mathrm{~W}$ & $\mathrm{R}$ & $\mathrm{S}$ & $\ldots$ & 1 \\
\hline Rhodococcus fascians & 9 & W & $\mathrm{R}$ & $\mathrm{S}$ & $\ldots$ & 1 \\
\hline Stenotrophomonas maltophilia & 9 & $\mathrm{C}$ & $\mathrm{R}$ & $\mathrm{S}$ & $\ldots$ & 2 \\
\hline Variovorax sp. & 7 & $\mathrm{~W}$ & $\mathrm{R}$ & $\mathrm{S}$ & $\ldots$ & 1 \\
\hline Unidentified & $5-7$ & $\mathrm{C}$ & $\mathrm{G}, \mathrm{R}$ & $\mathrm{S}$ & $\ldots$ & $1-2$ \\
\hline
\end{tabular}

a Blossoms were sampled from cvs. Gals (G) and Red Delicious (R) at research orchards at Wenatchee (W) and Columbia View (C).

${ }^{\mathrm{b}}$ Identifications were based on fatty acid methyl ester profiles and $16 \mathrm{~S}$ rDNA sequence analyses.

${ }^{c}$ Ratio of the number of isolates from stigmas to the number from hypanthia.

d Number of blossoms from which a strain was isolated on a given sampling date. Forty blossoms were collected per cultivar at each site. 
and a few new taxa were detected, including bacteria Paenibacillus spp., three additional species of Bacillus, and the yeast Pichia guilliermondii. Criteria for presenting results of a taxon in Table 5 included a minimum of three assays performed on three different dates. For this reason, and the fact that identifications by $16 \mathrm{~S}$ and ITS sequence analyses post-dated the blossom assays, some bacterial taxa (e.g., Actinobacterium spp. in Tables 2 and 3) are not represented in Table 5.
Taxonomic groups of bacteria and yeasts are listed from lowest to highest mean AI (Table 5), an index indicating the degree to which E. amylovora was suppressed; taxa with the lowest AI mean values were the most effective as antagonists. The mean AI for the standard antagonist Pantoea agglomerans C9-1 was 0.02 $( \pm 0.01)$, which was numerically greater than any taxon consisting of multiple isolates with AI values averaged together. Of the bacteria isolated from apple blossoms, the group identified as

TABLE 4. Yeasts or yeastlike organisms isolated from stigmas $(\mathrm{S})$ and hypanthia $(\mathrm{H})$ of apple blossoms at two sites in central Washington State

\begin{tabular}{|c|c|c|c|c|c|c|}
\hline Year, taxon ${ }^{b}$ & Days after petal expansion & Site & Cultivar & Tissue & $\mathrm{S}: \mathrm{H}$ ratio $^{\mathrm{c}}$ & No. of blossoms ${ }^{\mathrm{d}}$ \\
\hline \multicolumn{7}{|l|}{1994} \\
\hline Aureobasidium pullulans & $3,6,9$ & $\mathrm{C}, \mathrm{W}$ & $\mathrm{G}, \mathrm{R}$ & $\mathrm{H}, \mathrm{S}$ & 1.5 & $1-15$ \\
\hline Cryptococcus magnus & 9 & $\mathrm{~W}$ & $\mathrm{R}$ & $\mathrm{H}$ & $\ldots$ & 1 \\
\hline Cryptococcus victoriae & 6,9 & $\mathrm{C}, \mathrm{W}$ & $\mathrm{G}, \mathrm{R}$ & $\mathrm{H}, \mathrm{S}$ & 8.0 & $1-8$ \\
\hline Cryptococcus spp. & 6 & $\mathrm{~W}$ & $\mathrm{G}, \mathrm{R}$ & $\mathrm{H}, \mathrm{S}$ & 3.0 & 4 \\
\hline Rhodotorula sp. & 6 & $\mathrm{~W}$ & $\mathrm{R}$ & $\mathrm{S}$ & $\ldots$ & 1 \\
\hline Unidentified & 6,9 & $\mathrm{C}, \mathrm{W}$ & $\mathrm{G}, \mathrm{R}$ & $\mathrm{H}, \mathrm{S}$ & 1.0 & 1 \\
\hline \multicolumn{7}{|l|}{1995} \\
\hline Aureobasidium pullulans & $2,5,7,9$ & $\mathrm{C}, \mathrm{W}$ & $\mathrm{G}, \mathrm{R}$ & $\mathrm{H}, \mathrm{S}$ & 3.7 & $1-52$ \\
\hline Cryptococcus magnus & 5 & $\mathrm{~W}$ & $\mathrm{G}$ & $\mathrm{S}$ & $\ldots$ & 3 \\
\hline Cryptococcus victoriae & $5,7,9$ & $\mathrm{C}, \mathrm{W}$ & $\mathrm{G}, \mathrm{R}$ & $\mathrm{H}, \mathrm{S}$ & 6.3 & $2-13$ \\
\hline Crytococcus spp. & $5,7,9$ & $\mathrm{C}, \mathrm{W}$ & $\mathrm{G}, \mathrm{R}$ & $\mathrm{H}, \mathrm{S}$ & 5.2 & $4-23$ \\
\hline Rhodotorula minuta & 7 & $\mathrm{~W}$ & $\mathrm{G}$ & $\mathrm{H}$ & $\ldots$ & 1 \\
\hline Rhodotorula sp. & 7,9 & $\mathrm{C}, \mathrm{W}$ & $\mathrm{G}, \mathrm{R}$ & $\mathrm{S}$ & $\ldots$ & 2 \\
\hline Starmerella bombicola & 9 & $\mathrm{~W}$ & $\mathrm{G}$ & S & $\ldots$ & 1 \\
\hline Unidentified & 7,9 & $\mathrm{C}, \mathrm{W}$ & $\mathrm{G}, \mathrm{R}$ & $\mathrm{H}, \mathrm{S}$ & 1.0 & 2 \\
\hline
\end{tabular}

${ }^{a}$ Blossoms were sampled from cvs. Gala $(\mathrm{G})$ and Red Delicious (R) at research orchards at Wenatchee (W) and Columbia View (C).

${ }^{\mathrm{b}}$ Identifications were based on fatty acid methyl ester profiles and internal transcribed spacer rDNA sequence analyses.

${ }^{c}$ Ratio of the number of isolates from stigmas to the number from hypanthia.

d Number of blossoms from which a strain was isolated on a given sampling date. Forty blossoms were collected per cultivar at each site.

TABLE 5. Epiphytic bacteria and yeasts from apple blossoms tested for antagonism toward Erwinia amylovora on stigmas of detached crab apple blossoms ${ }^{\text {a }}$

\begin{tabular}{|c|c|c|c|c|c|}
\hline Microbial type, taxon $^{\mathrm{b}}$ & No. of isolates & No. of assays ${ }^{\mathrm{c}}$ & Average $\mathrm{AI}^{\mathrm{d}}$ & $\pm \mathrm{SE}^{\mathrm{e}}$ & No. of isolates $<0.05 \mathrm{AI}^{\mathrm{f}}$ \\
\hline \multicolumn{6}{|l|}{ Bacteria } \\
\hline Pantoea agglomerans C9-1 & 1 & 18 & 0.02 & 0.01 & 1 \\
\hline Pantoea agglomerans & 36 & 56 & 0.11 & 0.03 & 19 \\
\hline Pseudomonas spp. & 3 & 5 & 0.42 & 0.29 & 0 \\
\hline Bacillus atrophaeus & 4 & 5 & 0.53 & 0.25 & 0 \\
\hline Pseudomonas putida & 37 & 41 & 0.57 & 0.11 & 3 \\
\hline Pseudomonas fluorescens & 31 & 35 & 0.59 & 0.15 & 8 \\
\hline Clavibacter michiganense & 2 & 3 & 0.63 & 0.13 & 0 \\
\hline Curtobacterium flaccumfaciens & 7 & 9 & 0.64 & 0.18 & 0 \\
\hline Paenibacillus spp. & 5 & 5 & 0.91 & 0.15 & 0 \\
\hline Pseudomonas syringae & 41 & 45 & 0.96 & 0.22 & 7 \\
\hline Bacillus cereus & 12 & 13 & 0.99 & 0.35 & 0 \\
\hline Bacillus pumilus & 46 & 50 & 1.11 & 0.14 & 0 \\
\hline Arthrobacter aurescens & 3 & 3 & 1.18 & 0.85 & 0 \\
\hline Bacillus subtilis & 9 & 14 & 1.23 & 0.26 & 0 \\
\hline Arthrobacter spp. & 3 & 4 & 1.55 & 0.84 & 0 \\
\hline Microbacterium spp. & 7 & 7 & 1.8 & 0.49 & 0 \\
\hline Arthrobacter globiformis & 5 & 6 & 1.8 & 0.62 & 0 \\
\hline Bacillus megaterium & 31 & 33 & 1.93 & 0.60 & 0 \\
\hline Arthrobacter oxydans & 6 & 7 & 2.51 & 0.80 & 0 \\
\hline \multicolumn{6}{|l|}{ Yeasts (or yeastlike) } \\
\hline Cryptococcus magnus & 7 & 8 & 0.32 & 0.10 & 2 \\
\hline Rhodotorula spp. & 8 & 8 & 0.63 & 0.13 & 0 \\
\hline Cryptococcus victoriae & 15 & 15 & 0.64 & 0.13 & 0 \\
\hline Pichia guilliermondii & 11 & 15 & 0.34 & 0.08 & 0 \\
\hline Aureobasidium pullulans & 23 & 23 & 0.61 & 0.05 & 0 \\
\hline Cryptococcus spp. & 35 & 36 & 0.65 & 0.11 & 1 \\
\hline
\end{tabular}

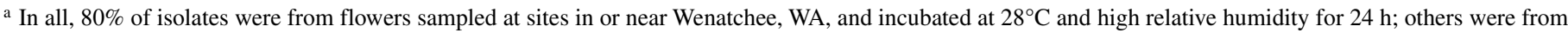
nonincubated flowers sampled at Wenatchee sites or Corvallis, OR.

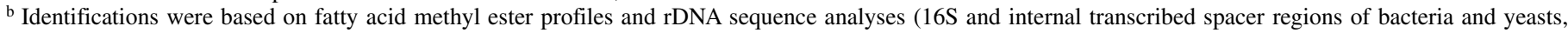
respectively).

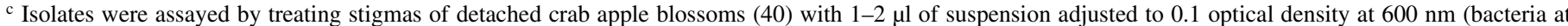
$\approx 10^{8} \mathrm{CFU} / \mathrm{ml}$ and yeast at $\approx 3 \times 10^{8} \mathrm{CFU} / \mathrm{ml}$ ), incubating the flowers for $24 \mathrm{~h}$ at $24^{\circ} \mathrm{C}$, then similarly inoculating the flowers with E. amylovora at $10^{7} \mathrm{CFU} / \mathrm{ml}$ and incubating them again. Generally, five flowers were used per isolate and 5 to 25 isolates were tested together per date and compared with control flowers inoculated with E. amylovora only. Some isolates were tested more than once.

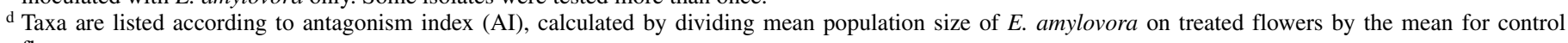
flowers.

e $\mathrm{SE}=$ standard error.

f Number of isolates with AI of $<0.05$, indicating a high degree of suppression. 
Pantoea agglomerans gave the lowest mean AI, which was 0.11 $( \pm 0.11)$. Other groups with mean AI values of $<0.6$ were pseudomonads, except for B. atrophaeus. When AI values were averaged for isolates in some taxa, mean AI was $\geq 1.0$, indicating that there was no suppression of E. amylovora or that test organisms may even have enhanced growth of the pathogen. Taxa highly represented in this category included B. pumilus and B. megaterium. As further assessment of the potential of bacterial taxa as antagonists, the number of isolates in each taxon with AI values of $<0.05$ (Table 5) were indicated; the AI for single isolates tested on one date was generally an average of results with five flowers, and most isolates with an AI of $<0.05$ were tested on more than one date. A total of 19 isolates in a group of 36 identified as Pantoea agglomerans gave $\mathrm{AI}$ values of $<0.05$, indicating high suppression of E. amylovora. Other bacterial taxa with representatives showing this level of suppression were Pseudomonas putida (three isolates), Pseudomonas fluorescens (eight isolates), and Pseudomonas syringae (seven isolates).

Tests with yeasts identified as Cryptococcus magnus and Pichia guilliermondii resulted in mean AI values of 0.32 and 0.34 , respectively (Table 5). The AI means for other yeasts or yeastlike organisms were 0.61 to 0.65 . Two isolates of $C$. magnus and one isolate identified only as Cryptococcus sp. had AI values of $<0.05$.

\section{DISCUSSION}

The frequency of microbial populations on apple blossom tissues was generally low on newly opened apple blossoms, as previously shown in a similar study with pear (52). Some microorganisms present on blossoms prior to petal expansion may overwinter within floral buds $(4,38)$. Sources of inoculum for colonization after petal expansion include organisms associated with adjacent blossoms or leaves and herbaceous plants in the orchard $(31,49)$. At Corvallis, OR, weeds were minimally managed in the study orchard and likely served as a source of epiphytic bacteria. Rain, which occurred often at Corvallis in 1995, is reported to disperse bacteria from the atmosphere (12). In central Washington State, some microbes may have come from the drift of under-canopy irrigation water piped from a canal to orchard blocks at Wenatchee or from the Columbia River to orchards at Columbia View. At the latter location, fine soil particles have been observed associated with flower parts; therefore, we suspect wind-blown soil as another inoculum source. Microorganisms also may have been dispersed by pollinating insects from nearby research or commercial apple and pear orchards.

In both years of the study, frequencies and population sizes of bacteria on stigmas of apple blossoms were notably greater at Corvallis, OR than at locations in central Washington State, a result consistent with the earlier pear study (52). The highest isolation incidences for any sampling date during bloom in Corvallis in 1994 and 1995 was 93 and 100\%, respectively. By comparison, in Washington, highest incidences for four apple orchard blocks was 23 to $78 \%$ in 1994 and 60 to $93 \%$ in 1995 . Highest mean population sizes of bacteria on stigmas of blossoms sampled in Corvallis were between two and three log units greater than the highest levels estimated for blossoms sampled in Washington.

The contrasting results in Washington and Oregon may be explained by differences in environmental conditions. Temperature, which is considered to be a major factor positively correlated with colonization of E. amylovora (7) and applied bacterial antagonists $(24,45)$, was actually higher in Washington than Corvallis; average temperatures during the sampling periods in Wenatchee, Washington, in 1994 and 1995 were 14.9 and $11.9^{\circ} \mathrm{C}$, respectively, and averages in Corvallis for these years were 11.9 and $8.4^{\circ} \mathrm{C}$, respectively. Rainfall was negligible at all locations, except at Corvallis in 1995. Possibly the contrast in results between locations in Washington and the site at Corvallis relates to relative humidity. The average relative humidity during blossom sampling in 1994 and 1995 was only 51.6 and 57.6\% in Wenatchee, respectively, but 82.9 and $84.7 \%$ in Corvallis, respectively. Inoculations of blossoms with E. amylovora in controlled environment studies indicate that bacterial growth on the stigma is much less affected by low relative humidity than is growth in the hypanthium $(43,55)$ but, nevertheless, is affected to some degree on stigmas (43). This effect could be greater for natural colonization initiated by only a few bacterial cells compared with assays in which blossoms were inoculated with hundreds or thousands of cells. Further, nonpathogenic indigenous bacteria found on pomaceous blossoms are generally less osmotolerant than E. amylovora (41) and, thus, more sensitive than the pathogen to dry environments. Although the relation of relative humidity to bacterial colonization on blossoms is not a focus of the present study, our observations do raise the question of whether relative humidity should be investigated further to improve systems for predicting potential growth of E. amylovora (7) or microbial antagonists (24) on blossoms.

The application of oxytetracycline sprays in 1994 to three of four orchard blocks evaluated in Washington was unanticipated and undesired but represents standard management practices in Washington apple orchards. Nonetheless, the incidence of bacterial isolation from blossom stigmas in the one untreated block was similar to results of two antibiotic-treated blocks. The frequency of bacteria was particularly low in another treated block, though this was indicated even before antibiotic treatment. Oxytetracycline, which has been shown to have a bacteriostatic effect on E. amylovora on blossoms (34), likely affected the colonization and growth of nonpathogenic indigenous bacteria on blossoms, but did not appear to have a dramatic effect. Stockwell et al. (51) inferred that oxytetracycline did not eradicate bacterial antagonist populations already established on blossoms but only slowed the rate of their growth. When flowers from oxytetracycline-treated trees were incubated at high temperature and high relative humidity in 1994, a steep decline in bacterial frequency and population size occurred after day 3 , which may have resulted from residual antibiotic activity. Given the high temperatures that occurred from day 3 to day 7, however, the decline also could be explained by an increase in the rate at which blossoms senesced and became less conducive for bacterial growth (45). The incubation of flowers at $28^{\circ} \mathrm{C}$ for $24 \mathrm{~h}$ would have further accelerated flower aging.

Bacterial frequencies and population sizes were similar on stigmas and hypanthia of blossoms at time of sampling in 1994 but tended to be somewhat higher on stigmas than on hypanthia in 1995, as was usually the case with pear (52). The same can be said for the yeasts or yeastlike organisms, a group not covered in the earlier pear report. Yeasts were detected on blossoms at frequencies and population sizes comparable with bacteria, which is interesting given the much larger size and mass of yeast cells. When selected isolates of bacteria and yeasts were cultured, suspended, and washed in water at known concentrations, then dried and weighed, it was estimated that the gram dry weight of yeast cells was $\approx 100 \times$ that of an equivalent number of bacterial CFU (data not shown). Thus, in terms of mass, the quantity of yeasts isolated from blossoms soon after they were collected from the orchard far surpassed that of bacteria. Bacterial frequencies and population sizes were generally higher than those of yeasts on blossom tissues during early sampling but, as flowers aged, yeast levels eventually surpassed bacteria. This trend, though slight and not evaluated statistically, was consistent in all four apple blocks during both years of the study. When sampled flowers were incubated in 1994, there was a dramatic shift in predominance from bacteria to yeasts but, as discussed, the bacterial decline was likely due, at least in part, to oxytetracycline. In 1995, when 
temperatures were cooler (overall average of 12 compared with $15^{\circ} \mathrm{C}$ in 1995) and blossom longevity was likely extended (45), bacterial levels remained high on incubated flowers throughout the sampling period but yeast frequencies and population sizes started low and reached maximum levels between day 5 and 9. Although results offer a weak case for the succession of bacteria to yeast on blossoms, a microbial shift like the one suggested has been described for the aerial surfaces of other plant tissues as they mature and senesce (3).

At the Corvallis orchard, $95 \%$ of the bacteria isolated from stigmas were identified as fluorescent pseudomonads. Pseudomonas fluorescens, Pseudomonas putida, and Pseudomonas syringae were similarly prominent in 1994. In 1995, 77\% of all bacterial isolates from Corvallis were Pseudomonas syringae, which has been described by others as a predominant part of the microflora of apple buds and blossoms $(4,32)$. By comparison, bacterial taxa isolated from blossoms at locations in Washington were more diverse. These results again parallel those of the pear study (52) in which the bacterial populations on blossoms at Corvallis, consisting mainly of pseudomonads, were present at levels that were higher but less diverse than populations on blossoms at an orchard in central Washington. As discussed, temperatures were higher but relative humidity and rainfall was lower at locations in Washington compared with the site at Corvallis. In a study focused on microbial survival in nectar, isolates of Pseudomonas spp. from apple blossoms were found to be less osmotolerant than members of other taxa, including enteric bacteria and Bacillus spp. (41). Possibly, under the lower moisture conditions in Washington, a diversity of bacteria colonize apple blossoms and coexist at low levels without being competitively excluded by Pseudomonas spp. In 1995, when temperatures were cooler and relative humidity was slightly higher in central Washington, the frequencies and population sizes of pseudomonads were noticeably higher than in the previous year. An increase in pseudomonads from 1994 to 1995 was observed even for the Red Delicious block not treated with oxytetracycline.

In addition to Pseudomonas, other bacterial genera most frequent on apple blossoms in central Washington were Actinobacterium, Bacillus, Curtobacterium, and Microbacterium. Yeasts or yeastlike organisms were less diverse and mainly belonged to the genera Aureobasidium and Cryptococcus. These major bacterial and yeast taxa were represented at population sizes of $\geq 10^{3} \mathrm{CFU}$ on blossoms of both Gala and Red Delicious at two orchard locations, and on both stigmatic and hypanthial tissues. Colonization of apple blossoms is more often initiated on stigmas, perhaps because the stigmatic tissues physically extend beyond the anthers and are more exposed to the environment and insects than tissues of the hypanthium, which is concave and covered by the anther filaments. Under dry conditions, the stigma is also a more suitable habitat for microbial colonization than the hypanthium, where nectar sugar is secreted and osmotic pressures can limit growth $(20,41)$. During our 2-year study, the ratio of the isolate number from stigmas to the isolate number from hypanthia $(\mathrm{S}: \mathrm{H})$ for bacteria and yeasts was comparable (4.5 and 3.6, respectively); however, ratios of specific taxa were less similar. For instance, the $\mathrm{S}: \mathrm{H}$ ratio was 8.0 for pseudomonads but only 3.0 for A. pullulans, indicating that pseudomonads may be less adapted to the hypanthium than $A$. pullulans. This is consistent with another study (41) in which indigenous microorganisms from apple blossoms were shown to vary in their capacity to grow in artificial nectar. Strains of A. pullulans were among those most adapted to high-sugar media, whereas strains of Pseudomonas spp. were the least osmotolerant.

Populations of E. amylovora at $>10^{3}$ were infrequent on apple blossoms, as observed in the earlier pear study (52), even though the fire blight risk in both studies was sometimes high according to the Cougarblight risk assessment model (50). An absence or low level of E. amylovora during periods when weather-based models signal a high disease risk is not uncommon (56), underscoring the need for practical and rapid methods of pathogen detection that can be coupled with present disease forecasting models (53). Pantoea agglomerans, a bacterium that has been isolated from apple tree tissues $(19,64)$ and shown to be an effective colonizer of pomaceous blossoms $(23,44,45,63)$, was also a minor resident on floral tissues of apple in the study reported here. Because strains of Pantoea agglomerans are known to be successful colonizers of blossoms under various weather conditions, we assume that inoculum of indigenous strains was limiting.

The incubation of Gala apple blossoms at high relative humidity and $28^{\circ} \mathrm{C}$, which is near the optimum temperature for growth of E. amylovora $(45,48)$, encouraged the multiplication of indigenous microorganisms on flower surfaces under conditions highly favorable for the fire blight pathogen. Results also indicated the potential of flower tissues to support microbial growth during the days following petal expansion and demonstrated that microbial growth in the orchard was primarily limited by environmental factors. The procedure resulted in an increase of detectable microbial taxa from blossoms, including additional species of Bacillus and the yeast Pichia guilliermondii that could later be evaluated as potential antagonists of E. amylovora. It also generated more isolates of Pantoea agglomerans, which are of particular interest because of previous studies indicating their potential in biological control of fire blight $(17,19,22)$. The capacities of different microorganisms to competitively exclude E. amylovora on pomaceous blossoms in the laboratory were previously reported to correspond to their relative antagonism toward the pathogen on blossoms in orchard environments (35, $36,40)$. Further, it has been established that suppression of $E$. amylovora on floral surfaces reduces the risk and incidence of fire blight $(7,22,24)$. When microbial isolates from apple representing a number of taxa were assayed on detached crab apple flowers, members of Pantoea agglomerans were most effective in preemptively excluding E. amylovora from stigmatic surfaces. This confirms the importance of this group as a source of antagonists for fire blight control $(17,19,22)$. One of the isolates tested was strain E325, which was later evaluated and compared with other strains of Pantoea agglomerans (42) (P. L. Pusey, unpublished data), and eventually became the active ingredient in the commercial product, Bloomtime Biological (Northwest Agricultural Products, Pasco, WA). Pseudomonads varied widely as antagonists but a few isolates of each species (Pseudomonas fluorescens, Pseudomonas syringae, and Pseudomonas putida) were highly effective against E. amylovora. Although Pseudomonas fluorescens A506 was not originally selected for capacity to reduce incidence of fire blight (27), it became the first commercial biocontrol agent (BlightBan A506) for managing this disease, and has been studied extensively as a component of antagonist mixtures $(22,23)$, in which it complements the antagonist Pantoea agglomerans C9-1 (BlightBan C9-1; Nufarm Americas Inc.). Other fluorescent pseudomonads have been investigated as potential antagonists of E. amylovora $(8,10)$. Results with Bacillus spp., which have the commercially desirable characteristic of forming endospores that are highly stable, were disappointing. In the current study, many isolates representing five different species of Bacillus had little or no effect on E. amylovora, and some may have even encouraged growth of the pathogen. Although commercial products for fire blight include two that include $B$. subtilis as an active ingredient, Serenade (AgraQuest, Davis, CA) and BioPro (Biosystem GmbH, Konstanz, Germany) (9), these products may have a mode of action that is more similar to antibiotics than biological control agents. Formulations of Serenade contain both antimicrobial lipopeptides produced by $B$. subtilis QST713 and endospores of this bacterium.

The yeast taxa with highest efficacy overall, based on an average antagonism index, were C. magnus and Pichia guillier- 
mondii. Two isolates of C. magnus and one unidentified Cryptococcus sp. were particularly effective. Mercier and Lindow (35) found that certain strains of Cryptococcus spp. originally isolated from apple fruit and shown to reduce postharvest fungal decay of apple fruit were also antagonistic to E. amylovora on pear blossoms. Yeasts or yeastlike organisms are of interest as antagonists on pomaceous blossoms because of their greater adaptability to high osmotic pressures, particularly on hypanthial surfaces during periods of low moisture.

The study provided detailed information relating to the colonization, growth, and identity of culturable, indigenous bacteria and yeasts on apple blossom tissues during the days following petal expansion. Further, blossom assays performed with numerous isolates representing most of the taxa identified indicated the potential of specific groups as sources of additional antagonists for use in fire blight management. New strains may be sought for use as single antagonists or antagonist mixtures composed of highly effective microbial strains that fill slightly different ecological niches or have complementary modes of antagonism.

\section{ACKNOWLEDGMENTS}

We thank J. Duffy, B. Steady, B. Blaisdell, and S. Ivanov for technical assistance and Van Well Nursery for providing trees.

\section{LITERATURE CITED}

1. Amann, R. I., Ludwig, W., and Schleifer, K. H. 1995. Phylogenetic identification and in situ detection of individual microbial cells without cultivation. Microbiol. Rev. 59:143-169.

2. Andrews, J. H. 1985. Strategies for selecting antagonistic microorganisms from the phylloplane. Pages 31-44 in: Biological Control on the Phylloplane. C. Windels and S. E. Lindow, eds. American Phytopathological Society, St. Paul, MN.

3. Andrews, J. H., and Harris, R. F. 2000. The ecology and biogeography of microorganisms on plant surfaces. Annu. Rev. Phytopathol. 38:145-180.

4. Andrews, J. H., and Kenerley, C. M. 1980. Microbial populations associated with buds and young leaves of apple. Can. J. Bot. 58:847-855.

5. Ark, P. A., and Hunt, M. L. 1941. Saprophytes antagonistic to phytopathogenic and other microorganisms. Science 93:354-355.

6. Beattie, G. A., and Lindow, S. E. 1995. The secret life of foliar bacterial pathogens on leaves. Annu. Rev. Phytopathol. 33:145-172.

7. Billing, E. 2000. Fire blight risk assessment systems and models. Pages 235-252 in: Fire Blight: The Disease and Its Causative Agent, Erwinia amylovora. J. L. Vanneste, ed. CAB International, Wallingford, UK.

8. Biondi, E., Bazzi, C., and Vanneste, J. L. 2006. Reduction of fire blight incidence on apple flowers and colonization of pear shoots in experimental orchards using Pseudomonas spp. IPV-BO G19 and IPV-BO 3371. Acta Hortic. 704:323-327.

9. Broggini, G. A. L., Duffy, B., Holliger, E., Schärer, H.-J., Gessler, C., and Patocchi, A. 2005. Detection of the fire blight biocontrol agent Bacillus subtilis BD170 (Biopro) in a Swiss apple orchard. Eur. J. Plant Pathol. 111:93-100.

10. Cabrefiga, J., Bonaterra, A., and Montesinos, E. 2007. Mechanisms of antagonism of Pseudomonas fluorescens EPS62e against Erwinia amylovora, the causal agent of fire blight. Int. Microbiol. 10:123-132.

11. Chen, Y.-C., Eisner, J. D., Kattar, M. M., Rassoulian-Barrett, S. L., Lafe, K., Limaye, A. P., and Cookson, B. T. 2001. Polymorphic internal transcribed spacer region 1 DNA sequences identify medically important yeasts. J. Clin. Microbiol. 39:4042-4051.

12. Constantinidou, H. A., Hirano, S. S., Baker, L. S., and Upper, C. D. 1990. Atmospheric dispersal of ice nucleation-active bacteria-the role of rain. Phytopathology 80:934-937.

13. Duffy, B., Vogelsanger, J., Schoch, B., and Holliger, E. 2006. Biocontrol of Erwinia amylovora using a commercial yeast strain mixture. Acta Hortic. 704:363-366.

14. El-Goorani, M. A., and Hassanein, F. M. 1991. The effect of Bacillus subtilis on in vitro growth and pathogenicity of Erwinia amylovora. J. Phytopathol. 133:134-138.

15. Environmental Protection Agency, Biopesticides and Pollution Division. 2006. Pantoea agglomerans strain C9-1; exemption from the requirement of a tolerance. EPA, Washington, DC. Federal Register 71(80):2459024596.

16. Environmental Protection Agency, Biopesticides and Pollution Division. 2006. Pantoea agglomerans strain E325; exemption from the requirement of a tolerance. EPA, Washington, DC. Federal Register 71(182):5492854933

17. Epton, H.A.S., Wilson, M., Nicholson, S. L., and Sigee, D.C. 1994. Biological control of Erwinia amylovora with Erwinia herbicola. Pages 335-352 in: Ecology of Plant Pathogens. J. P. Blakeman and B. Williamson, eds. CAB International, Wallingford, UK.

18. Ishimaru, C., and Klos, E. J. 1984. New medium for detecting Erwinia amylovora and its use in epidemiological studies. Phytopathology 74:1342-1345

19. Ishimaru, C. A., Klos, E. J., and Brubaker, R. R. 1988. Multiple antibiotic production by Erwinia herbicola. Phytopathology 78:746-750.

20. Ivanoff, S. S., and Keitt, G. W. 1941. Relations f nectar concentration to growth of Erwinia amylovora and fire blight infection of apple and pear blossoms. J. Agric. Res. 62:733-743.

21. Jelkmann, W., and Lindner, A. 2008. Studies on antagonistic yeast species against Erwinia amylovora in co-culture and on apple blossoms. Acta Hortic. 793:403-408.

22. Johnson, K. B., and Stockwell, V. O. 2000. Biological control of fire blight. Pages 319-337 in: Fire Blight: The Disease and Its Causative Agent, Erwinia amylovora. J. L. Vanneste, ed. CAB International, Wallingford, UK.

23. Johnson, K. B., Stockwell, V. O., McLaughlin, R. J., Sugar, D., Loper, J. E., and Roberts, R. G. 1993. Effect of antagonistic bacteria on establishment of honey bee-dispersed Erwinia amylovora in pear blossoms and on fire blight control. Phytopathology 83:995-1002.

24. Johnson, K. B., Stockwell, V. O., and Sawyer, T. L. 2004. Adaptation of fire blight forecasting to optimize the use of biological controls. Plant Dis. 88:41-48.

25. Lane, D. J. 1991. 16S/23S rRNA sequencing. Pages 115-147 in: Nucleic Acid Techniques in Bacterial Systematics. E. Stackebrandt and M. Goodfellow, eds. Wiley, New York.

26. Leben, C., and Sleesman, J. P. 1982. Preservation of plant-pathogenic bacteria on silica gel. Plant Dis. 66:327.

27. Lindow, S. E. 1985. Integrated control and role of antibiosis in biological control of fire blight and frost injury. Pages 83-115 in: Biological Control on the Phylloplane. C. Windels and S. E. Lindow, eds. The American Phytopathological Society, St. Paul, MN.

28. Lindow, S. E., and Brandl, M. T. 2003. Microbiology of the phyllosphere. Appl. Environ. Microbiol. 69:1875-1883.

29. Lindow, S. E., Hecht-Poinar, E. I., and Elliott, V. 2002. Phyllosphere Microbiology. The American Phytopathological Society, St. Paul, MN.

30. Lindow, S. E., McGourty, G., and Elkins, R. 1996. Interactions of antibiotics with Pseudomonas fluorescens strain A506 in the control of fire blight and frost injury to pear. Phytopathology 86:841-848.

31. Malvick, D. K., and Moore, L. W. 1988. Population dynamics and diversity of Pseudomonas syringae on maple and pear trees and associated grasses. Phytopathology 78:1366-1370.

32. Mansvelt, E. L., and Hattingh, M. J. 1988. Resident populations of Pseudomonas syringae pv. syringae on leaves, blossoms, and fruits of apple and pear trees. J. Phytopathol. 121:135-142.

33. Mazzola, M., and Gu, Y.-H. 2002. Wheat genotype-specific induction of soil microbial communities suppressive to disease incited by Rhizoctonia solani anastomosis group (AG)-5 and AG-8. Phytopathology 92:13001307.

34. McManus, P. S., and Jones, A. L. 1994. Epidemiology and genetic analysis of streptomycin-resistant Erwinia amylovora from Michigan and evaluation of oxytetracycline for control. Phytopathology 84:627-633.

35. Mercier, J., and Lindow, S. E. 1996. A method involving ice nucleation for the identification of microorganisms antagonistic to Erwinia amylovora pear flowers. Phytopathology 86:940-945.

36. Mercier, J., and Lindow, S. E. 2001. Field performance of antagonistic bacteria identified in a novel laboratory assay for biological control of fire blight of pear. Biol. Control 22:66-71.

37. Miller, L., and Berger, T. 1985. Bacterial identification by gas chromatography of whole cell fatty acids. Hewlett-Packard Application Note 228-41. Hewlett-Packard Co., Avondale, PA.

38. Montesinos, E., and Vilardell, P. 1991. Relationships among population levels of Pseudomonas syringae, amount of ice nuclei, and incidence of blast of dormant flower buds in commercial pear orchards in Catalunya, Spain. Phytopathology 81:113-119.

39. Psallidas, P. G., and Tsiantos, J. 2000. Chemical control of fire blight. Pages 199-234 in: Fire Blight: The Disease and Its Causative Agent, Erwinia amylovora. J. L. Vanneste, ed. CAB International, Wallingford, UK.

40. Pusey, P. L. 1997. Crab apple blossoms as a model for research on biological control of fire blight. Phytopathology 87:1096-1102.

41. Pusey, P. L. 1999. Effect of nectar on microbial antagonists evaluated for use in control of fire blight of pome fruits. Phytopathology 89:39-46.

42. Pusey, P. L. 1999. Control of fire blight on pome fruit trees with Erwinia herbicola. United States Patent No. 5,919,446. 
43. Pusey, P. L. 2000. The role of water in epiphytic colonization and infection of pomaceous flowers by Erwinia amylovora. Phytopathology 90:1352-1357.

44. Pusey, P. L. 2002. Biological control agents for fire blight of apple compared under conditions limiting natural dispersal. Plant Dis. 86:639644.

45. Pusey, P. L., and Curry, E. A. 2004. Temperature and pomaceous flower age related to colonization by Erwinia amylovora and antagonists. Phytopathology 94:901-911.

46. Pusey, P. L., Rudell, D. R., Curry, E. A., and Mattheis, J. P. 2008. Characterization of stigma exudates in aqueous extracts from apple and pear flowers. HortScience 43:1471-1478.

47. Raaijmakers, J., Weller, D. M., and Thomashow, L. S. 1997. Frequency of antibiotic-producing Pseudomonas spp. in natural environments. Appl. Environ. Microbiol. 63:881-887.

48. Schouten, H. J. 1987. A revision of Billing's potential doublings table for fire blight prediction. Neth. J. Plant Pathol. 93:55-60

49. Sobiczewski, P., Chiou, C.-S., and Jones, A. L. 1991. Streptomycinresistant epiphytic bacteria with homologous DNA for streptomycin resistance in Michigan apple orchards. Plant Dis. 75:1110-1113.

50. Smith, T. J. 1999. Report on the development of and use of Cougarblight 98C - A situation specific fire blight risk assessment model for apple and pear. Acta Hortic. 489:429-436.

51. Stockwell, V. O., Johnson, K. B., and Loper, J. E. 1996. Compatibility of bacterial antagonists of Erwinia amylovora with antibiotics used to control fire blight. Phytopathology 86:834-840.

52. Stockwell, V. O., McLaughlin, R. J., Hendels, M. D., Loper, J. E., Sugar, D., and Roberts, R. G. 1999. Epiphytic colonization of pear stigmas and hypanthia by bacteria during primary bloom. Phytopathology 89:11621168.

53. Temple, T. N., Stockwell, V. O., and Johnson, K. B. 2008. Development of a rapid detection method for Erwinia amylovora by loop-mediated isothermal amplification (LAMP). Acta Hortic. 793:497-503.

54. Tewoldemedhin, Y. T., Lamprecht, S. C., McLeod, A., and Mazzola, M. 2006. Characterization of Rhizoctonia spp. recovered from crop plants used in rotational cropping systems in the Western Cape province of South Africa. Plant Dis. 90:1399-1406.

55. Thomson, S. V. 1986. The role of the stigma in fire blight infections. Phytopathology 76:476-482.

56. Thomson, S. V. 2000. Epidemiology of fire blight. Pages 9-36 in: Fire Blight: The Disease and Its Causative Agent, Erwinia amylovora. J. L. Vanneste, ed. CAB International, Wallingford, UK.

57. Van der Zwet, T., and Beer, S. V. 1995. Fire blight-its nature, prevention, and control. U. S. Dep. Agric. Agric. Res. Serv. Inf. Bull. No. 631.

58. Van der Zwet, T., and Keil, H. L. 1979. Fire blight: bacterial disease of rosaceous plants. U. S. Dep. Agric. Sci. Ed. Admin. Agric. Handb. 510.

59. Vanneste, J. L., Cornish, D. A., Yu, J., and Voyle, M. D. 2002. P10c: A new biological control agent for control of fire blight which can be sprayed or distributed using honey bees. Acta Hortic. 590:231-235.

60. Vanneste, J. L., Yu, J., Harper, G. E., and Perry, J. H. 1996. Plugs of immature pear fruit to assess the virulence of Erwinia amylovora and to study in the laboratory the interaction between biological control agents and the fire blight pathogen. Acta Hortic. 411:303-307.

61. White, T. J., Bruns, T, Lee, S., and Taylor, J. W. 1990. Amplification and direct sequencing of fungal ribosomal RNA genes for phylogenetics. Pages 315-322 in: PCR Protocols: A Guide to Methods and Applications. M. A. Innis, D. H. Gelfand, J. J. Sninsky, and T. J. White, eds. Academic Press, New York.

62. Wilson, M., Epton, H. A. S., and Sigee, D. C. 1990. Biological control of fire blight of hawthorn (Crataegus monogyna) with Erwinia herbicola under protected conditions. Plant Pathol. 39:301-308.

63. Wilson, M., Epton, H. A. S., and Sigee, D. C. 1992. Interactions between Erwinia herbicola and E. amylovora on the stigma of hawthorn blossoms. Phytopathology 82:914-918.

64. Wodzinski, R. S., and Paulin, J. P. 1994. Frequency and diversity of antibiotic production by putative Erwinia herbicola strains. J. Appl. Bacteriol. 76:603-607.

65. Wrather, J. A., Kuc, J., and Williams, E. B. 1973. Protection of apple and pear fruit tissue against fire blight with nonpathogenic bacteria. Phytopathology 63:1075-1076. 